\title{
DETERMINANTS OF FIRM PERFORMANCE OF VIETNAMESE LISTED REAL ESTATE COMPANIES: THE EVIDENCE OF LEVERAGE THRESHOLD
}

\author{
THAI DUY TUNG, LY XUAN HAI, LAM THI KIEU MY \\ Industrial University of Hochiminh City \\ thaiduytung@iuh.edu.vn,lyxuanhai@iuh.edu.vn,lamthikieumy@iuh.edu.vn
}

\begin{abstract}
The aim of this paper is finding empirical evidences for the existence of factors that influence firm performance of Vietnamese listed real estate companies. A single threshold panel regression analysis is conducted to confirm threshold effect of leverage. Because of the leverage threshold effect, the impacts of firm growth, firm size, and leverage on firm performance differ in the region below and above debt to equity ratio at the level of 0.383 . Performance of less levered firms are also less likely to statistically response to the determinants while the empirical evidences of impacts can be found in companies that pass the leverage threshold.
\end{abstract}

Keywords. determinant, firm performance, panel data, real estate, threshold, Vietnam.

\section{INTRODUCTION}

In recent years, the economic growth of Vietnam has recovered in line with the upswing of the global economy. Historical data from World Bank shows an uptrend of GDP growth rate of Vietnam from the low level of 5.2 percent in 2012 to 6.8 percent in 2017. During that period, the GDP growth of the world changed in the range of 2.5 percent in 2012 and 3.1 percent in 2017. Undoubtedly, Vietnam has remained its outperformance of economic growth in the context of slow global recovery after the financial crash in 2007-2008.

The economic recovery facilitated the demand of residential property, especially in major cities. According to report of [21], urbanisation rate of Vietnam is 2.6 percent, the highest rate in ASEAN. Strong residential demand could be seen in both the biggest cities, Hanoi and Hochiminh City. In addition, the policy packages that support real estate market, such as direct funding, taxation, interest rates etc..., have been implemented during this period as a result of the previous "frozen" session of the real estate market.

The fact creates opportunities for real estate firms to enjoy phenomenal growth and profitability. In an emerging market like Vietnam, real estate market makes remarkable impacts on the economy as a whole. Since 2010, half of the top wealthiest Vietnamese are the owners of real estate companies, such as Vin Group, FLC, Novaland etc .... It can be stated that this period is the "Golden Age" of the real estate industry in Vietnam. Before this time, according to Hochiminh City Real Estate Association, the real estate market has experienced a complete business cycle including growing, booming, slowing down, recessing, recovering, and slowly growing stage during the last 20 years. The market enjoyed rapid growth during the period between 2003 and 2006, before going into the crash in 2008 and the long recession from 2011 to 2013. After 2013, Vietnamese real estate market recovered slowly and started to soar since 2016. Each stage of real estate market often resulted in the co-movement of the stock market and banking system, as well as capital flows. Undoubtedly, the temperature of real estate market in Vietnam can affect macroeconomic activities through its impacts on urbanisation, infrastructure development, fiscal policies, monetary policies, and even the legal system. Research on real estate industry thus completes both the theoretical and empirical understandings of Vietnamese economy, a rising and potential market to international stakeholders.

The attraction of high profit margin makes real estate one of the most competitive industries in Vietnam in terms of economic powers, technologies, and management. The movement therefore makes 
impacts on firm performance in real estate industry. Discovering the determinants of firm performance is thus a challenge to Vietnamese real estate companies in order to survive in such highly competitive market.

The determinant of firm performance is a popular topic in the study of finance. However, the firm performance of Vietnamese real estate listed companies has not been fully researched so far. The studies of [3], [19] or [1] have found some empirical evidences of the determinants on Vietnamese real-estate firm performance but the disagreement on the impacts and signs of the relationship has existed. The inconsistency in results of previous studies infers changing behaviours of factors, or perhaps the relationship might not be linear. There could be a likelihood of "break" over a threshold through which the correspondence of firm performance to its determinants would change. That reasoning suggested the authors to conduct this study.

This research aims at developing the empirical evidences of the topics by employing threshold panel regression. If the threshold effect is confirmed, this paper will contribute valuable findings for a more comprehensive analysis and discussion on endogenous and exogenous factors that affect firm performance of Vietnamese real-estate listed companies. Consequently, more detailed implications for policies at firm level can be made to achieve better performance in real estate industry in Vietnam.

\section{LITERATURE REVIEW}

\subsection{Real estate industry in Vietnam}

Laws and regulations in most countries commonly consider real estate lands and properties on those lands. According to Vietnamese law, in particular the Civil Law 2005, real estate includes land, construction on land, and other assets as integral parts of that land that regulated by the law. Real estate is either a special asset class, a research topic or a business.

[14] categorized real estates in Vietnam into the following groups: 1) Residential houses are either single houses, apartments or land area on which single houses or apartment buildings are constructed, 2) Commercial real estates are offices for rent, shopping malls, markets, stores, hotels, restaurants, resorts and available lands on which such buildings are constructed ,3) Industrial real estates are plants, warehouses, facilitating buildings, mines and lands related to mentioned constructions, 4) Agricultural, Forestry, and Fishery real estates are forests, aquacultural areas, farms, and drainage systems, 5) Public real estates are the State owned offices, public hospitals, parks roads, schools and other communitybeneficial buildings, and 6) Alternative real estates are the ones that cannot be classified into the mentioned groups, such as religious buildings, charity centres etc...

Real estate companies in Vietnam mainly have business in residential houses and commercial real estates whose growth is facilitated by population growth, increasing urbanisation rate and extending consumption of the growing middle class. Most of them are real estate developers which acquire potential land and develop residential and commercial projects. Seeking profits on procyclical basis, Vietnamese real estate companies depend much on economic cycles and money supply. However, the increasing urbanisation rate and population help maintaining a stable demand growth in the real estate market. The concern of real estate companies thus perhaps lie in the firm performance in different cycles.

\subsection{Theoretical foundation of firm performance and its determinants \\ Firm performance}

Firm performance may be illustrated by the relationship of resource exploitation and resource management to achieve given objectives of the business. In different stages of development, the goals may vary, but the ultimate objective of a profit-oriented organisation is most likely maximising profit by optimising the usage of the company's resources. In order to achieve these goals, the management team may employ a wide range of approaches and tools. And firm performance is one of the most useful tools for the managers to measure and assess the effectiveness and efficiency of their business. In addition, the analysis of firm performance provides crucial factors that have significant impacts on the firm's business. The results in turn suggest timely and appropriate changes in corporate governance to enhance the business. 
According to [16], firm performance can be measured in both financial and organisational perspective. As for financial aspect, the Return on Asset (ROA) and Return on Equity (ROE) are often the proxies for firm performance. In more advanced stock markets, the firm performance can be observed by market ratio, such as the Price to Earnings ratio, Market to Book ratio, or Tobin'Q. As for organisational aspect, firm performance can be assessed by evaluating factors such as: managerial efficiency, social efficiency, overall efficiency of all corporate functions including sales, marketing, customer service etc.

Under the research context that limits within the group of listed real estate companies in Vietnam stock market, the most appropriate measurement of firm performance should be the financial performance which is analysed by ROA and ROE, rather than the other ratios. Vietnam stock market is still in frontier or emerging market; therefore, it may be informationally inefficient and the market price is not likely to reflect the adequate firm performance.

\section{Determinants of firm performance}

Determinants of firm performance consist of 2 groups: endogenous factors and exogenous factors. Endogenous factors are the factors that can be controlled to a specific extent within the firm and employed to enhance the performance by corporate policies. The study of endogenous factors therefore fully meet the objectives of this papers, that is, exploring decisive factors of firm performance and suggesting policy implications that may be applicable in Vietnamese listed real estate companies. On the other hand, exogenous factors cannot be influenced by policies at corporate level. These factors thus may not contribute to implications for corporate policies. However, they should be considered to give a more comprehensive analysis of firm performance.

The endogenous group considered by the authors includes firm size, leverage, growth and age.

Firm size can be determined by total assets, net revenue or the number of employees [12]. The economies of scale infers that average expense per unit diminish along with the increase of quantity. Accordingly, return per unit and quantity have positive relationship. Economies of scale can be achieved by the decline of fixed cost, the increase of expertisation and the efficiency of purchase on large amounts. In addition, large-size firms possess more competitive features, such as reputation, brand identification, market share or financial strength. They also have greater access to low-cost finance. For those reasons, firm size has positive impact on profit and firm performance.

Leverage is often measured by the ratio of Debt on Equity or Debt on Total Asset. It shows the corporate capital structure and relative level of Debt on other sources of capital. [15] stated that capital structure and firm value were relevant in case of corporate tax. The aim of debt usage is taking advantage of fixed interest expense to increase residual income of equityholders. Because interest expense is tax deductible, the use of debt also creates benefit from interest tax shield and generates more after-tax cash flows. The firm value thus increases in line with the use of debt. Nevertheless, the increasing leverage also results in additional financial risk. Initially, low cost of debt and tax-shield benefit make the average cost of capital decrease if using more debt. When the capital structure achieves the "optimal" point, additional debt raises the cost of debt because of higher default risk. Therefore, [20] believed that highly levered firms would be more vulnerable and exposed to more risks in depression cycle.

Growth is another factor of firm performance. [9] concluded that firms with stable growth would be more efficient and survive, while smaller and less efficient firms experienced more variate growth rates, signalling more possibility of decline and failure. Recent positive growth rate, confirmed by [4], anticipated better firm performance.

Firm age is the number of years during which the firm exist in the industry. [4] found that most industrial exits happened in case of young firms, and large young firms survived longer than smaller ones. The companies with longer years of experience also accumulated more capital to finance their business. Their long-term network would play an important role in the competition. Thus, there would be a positive relationship between age and profit or firm performance.

Exogenous factors that affect firm performance can be political environment, laws and regulation, economic condition or macroeconomic policies such as the central bank's interest rate. In addition, researchers may consider social and cultural factors that are related to customers' behaviour, national 
income, technology, the level of development in infrastructure, competition, and bargain power of customers and suppliers. In the scope of this research, the authors analyse the impact of economic factors on firm performance, in particular, the GDP growth rate which is observable and has direct impacts on many other macroeconomic factors, such as national income, capital flows, money supply, interest rate policy, and inflation. Therefore, GDP growth is expected to have coherently positive correlation with firm performance.

\subsection{Previous studies on determinants of firm performance in Vietnamese real estate companies}

International empirical evidences of determinants of firm performance can be found in numerous previous studies.

[12] used ROA and ROE as proxies for firm performance of Greek companies. Their research confirmed the correlation of leverage, export activity, location, firm size, and efficient management with firm performance. Accordingly, Greek firms with great performance seem to be large, young, exporting firms with efficient management team. Furthermore, they would have optimal leverage and sufficient liquidity.

[24], testing on the sample of 167 Jordanian companies in the period between 1989 and 2003, found leverage, asset growth, firm size, corporate tax and industrial features as determinants of firm performance which was measured by ROA. Their study concluded a negative relationship between firm performance and capital structure, implying the overleverage of the sampled companies during the period under the study.

The negative impact of debt level on firm performance was also detected in the research of [18]. Based on the sample of 30 non-financial firms in Nigeria, the authors found the evidence of positive impacts of age and size on ROE. Also, ROE did well as the proxy for firm performance in companies of beverage and construction industry, while the model with ROA as dependent variable explained better in case of chemistry and printing industry. Undoubtedly, the use of ROE and ROA as the measurement for firm performance might not result in the same conclusion.

[20] and [10] found evidences of positive relationship of growth rate and ROA. The research of [20] agreed with some previous studies on the fact that leverage negatively affected firm performance. [17] did not find any statistical significance of age's impact on ROA of Kenyan insurance companies, while the influences of capital structure and size on profitability were revealed.

In Vietnam, researches on firm performance of listed companies have been conducted by [3], [19] and [1]. The study of [3], employing ROA as the proxy of firm performance, discovered that construction companies which were too credit intensive would be less profitable. However, [3] did not find the statistical evidences of impacts made by asset growth and firm size on firm performance. Papers of [19] and [1] derived the same conclusion regarding to negative impact of leverage on firm performance. Nonetheless, the two papers distincted in the other explainable variables. While variables of endogenous factors such as asset structure, treasury stocks, and firm age were mainly used in the study of [19] who also found inconsistent empirical results in case of different dependent variables - ROE and ROA - in their models, [1] employed GDP growth rate as the proxy for exogenous factors and confirmed positive influences of GDP growth and firm size on firm performance measured by ROA.

The distinctive empirical results in different research contexts and periods imply the inconsistent impacts of stated determinants on firm performance. The variation of impacts can be explained by the fact that economic relationships would change at some certain points which we call "threshold". In fact, most relationships will not be the same in long term, and a non-linear model is more likely to explain such correlations. [5] proposed an approach which estimated the effect of threshold on non-dynamic panels. [2] used this method to determine a triple-threshold effect and inverted-U shaped relationship between capital structure and firm value in China. Research of [13] also proved the non-linear impact of debt ratio on firm value in Taiwan, inferring estimation for optimal capital structure. Evidence for the optimal R\&D expense to maximise firm performance in Taiwanese listed information technology and electronic companies was found by [23].

Summary of previous studies can be found in the Table 1 . 
Table 1. Summary of the previous studies on determinants of firm performance

\begin{tabular}{lccc}
\hline Role of variable & Variable name & Studied by & $\begin{array}{c}\text { Sign of impact } \\
\text { (empirical result) }\end{array}$ \\
\hline Dependent variable & ROA & {$[1],[3],[10],[12]$} & \\
\hline Dependent variable & ROE & {$[17],[18],[19],[20][24]$} & + \\
\hline (Return on Equity) & {$[12],[18],[19]$} & Insignificant \\
Independent variable & Firm Size & {$[1],[18],[20],[24]$} & {$[3]$} \\
\hline Independent variable & & {$[10]$} & + \\
& Leverage & {$[1],[3],[17],[18],[19],[20]$,} & - \\
\hline Independent variable & Firm Growth & {$[1],[10],[18],[19],[20],[24]$} & + \\
\hline Independent variable & Firm Age & {$[3]$} & Insignificant \\
\hline Independent variable & GDP growth & {$[18],[19]$} & + \\
\hline Threshold variable & Debt ratio & {$[17],[13]$} & Insignificant \\
\hline Threshold variable & R\&D intensity & S23] & + \\
\hline
\end{tabular}

\section{RESEARCH METHODOLOGY}

\subsection{Research models}

\section{Panel regression model without threshold}

Aiming at discovering the determinants of firm performance in Vietnamese listed real estate companies, we develop our research models on the basis of findings by [12], [24], [20], [3], [18], [19], [10], [17], and [1]. Accordingly, firm performance is affected by firm growth, leverage, firm size, firm age, and GDP growth. Most previous studies used ROA as the proxy for firm performance, and we also share the same opinion because ROE is more distorted by financial policy of each firm.

The initial research model which is called Model 1 is illustrated in the Equation (1)

$$
R O A_{i t}=\beta_{0}+\beta_{1} G R O W T H_{i t}+\beta_{2} S I Z E_{i t}+\beta_{3} L E V_{i t}+\beta_{4} A G E_{i t}+\beta_{5} G D P_{t}+\varepsilon_{i t}
$$

Where: i: indicate the company in panel

$\mathrm{t}$ : indicate the time in panel

Dependent variable:

$R O A_{i t}$ : Return on Asset

Independent variable:

GROWTH $H_{i t}$ : firm growth

$S I Z E_{i t}:$ firm size

$L E V_{i t}$ : leverage

$A G E_{i t}$ : firm age

$G D P_{t}$ : GDP growth of Vietnam

\section{Panel regression model with threshold}

As being mentioned above, empirical results of Model 1 may be inconsistent because determinants at firm level may change their behaviours at some point. Therefore, the additional consideration of threshold effect is worthwhile in this study. We apply the single threshold model of [5] to find evidence of 
threshold effect on the impacts of leverage, firm age, size and firm growth. The single threshold creates two distinctive regions (or category), one below and one above the threshold, and these variables are considered region-varying. Leverage is both the independent variable and the threshold variable in this paper. The selection of threshold variable derived from the fact that Vietnamese real estate companies are relatively debt intensive. On average, debt to equity ratio is 1.6 (see Table 3), or nearly two thirds of company's capital financed by debt. The significant debt dependence may result in the variation of impacts caused by other determinants.

We have Model 2 in the Equation (2).

$$
R O A_{i t}=\left\{\begin{array}{c}
\alpha_{0}+\alpha_{1} G R O W T H_{i t}+\alpha_{2} S I Z E_{i t}+\alpha_{3} L E V_{i t}+\alpha_{4} A G E_{i t}+\mu G D P_{t}+\varepsilon_{i t} \text { if } L E V_{i t} \leq \theta_{0} \\
\beta_{0}+\beta_{1} G R O W T H_{i t}+\beta_{2} S I Z E_{i t}+\beta_{3} L E V_{i t}+\beta_{4} A G E_{i t}+\mu G D P_{t}+\varepsilon_{i t} \text { if } L E V_{i t}>\theta_{0}
\end{array}\right.
$$

Where: $\quad \mu$ is the co-efficient of region-invarying variable

\subsection{Research hypotheses} $\theta_{0}$ is the threshold of leverage

\section{Impact of Firm Growth on firm performance}

Firm with high and stable growth rate is expected to be more profitable. [9] and [4] argued that high-growth firm would survive in the competition and generate more potential cash flows. In addition, high-growth companies are often highly appreciated by growth investors whose buying pressure will raise the stock price. It also makes the lenders more optimistic. Consequently, companies with higher growth rate may be more accessible to finance for potential investment projects. [24], [20], [18], [19], and [1] found the positive impact of firm growth on firm performance. The hypothesis is:

\section{H1: Firm Growth has positive impact on ROA}

\section{Impact of Leverage on firm performance}

Most previous studies, except [12], found the negative relationship between leverage and ROA (see Table 1). Although the use of debt, according to [15], create additional cash flows in the form of tax shield, the rising default risk will soon raise the cost of debt, thus offsetting the advantage of interest tax shield. The development of financial markets has facilitated debt use, resulting in overleverage in most countries. The empirical results, thus, supported the following hypothesis:

H2: leverage has negative impact on ROA.

Impact of Firm Size on firm performance

As being discussed in Section 2, firm size is expected to have positive correlation with profit and firm performance because of the economies of scale, competitive advantages, and access to finance. In this paper, firm size is measured by the natural logarithm of total asset instead of the actual figures. The use of natural logarithm of total asset will reduce the potential of outliers in the research model.

H3: Firm size has positive impact on ROA

\section{Impact of Firm Age on firm performance}

The age of firm, calculated by subtracting the year of establishment from current year, reflects the level of capital accumulation and business experience. Long history also provides more information which facilitates financing decision of external investors. Therefore, firm age and ROA will have positive relationship, as confirmed by the empirical studies of [18] and [19].

H4: Firm age has positive impact on ROA

Impact of GDP growth on firm performance

GDP growth represents macroeconomic variables in the model. In case of procyclical industries such as real estate, the relationship of firm performance and macroeconomic conditions is even closer. In Vietnam, [1] found statistically significant result for that impact in the case of real estate industry.

H5: GDP growth rate has positive impact on ROA.

The summary of variables in the research models and research hypotheses is displayed in Table 2. 
Table 2. Summary of the variables in the research models

\begin{tabular}{|c|c|c|c|c|}
\hline Role of variable & Variable name & Formula & $\begin{array}{c}\text { Expected sign } \\
\text { of the } \\
\text { relationship }\end{array}$ & Source \\
\hline \multirow{2}{*}{ Dependent variable } & \multirow{2}{*}{$\begin{array}{c}\text { ROA } \\
\text { (Return on Asset) }\end{array}$} & Net Income & & \multirow{2}{*}{$\begin{array}{l}\text { Financial } \\
\text { Statements }\end{array}$} \\
\hline & & $\overline{\text { Average Total asset }}$ & & \\
\hline \multirow{2}{*}{ Independent variable } & \multirow{2}{*}{ Firm Size } & Natural logarithm of Total & & \multirow{2}{*}{$\begin{array}{c}\text { Financial } \\
\text { Statements }\end{array}$} \\
\hline & & Asset & + & \\
\hline \multirow{2}{*}{ Independent variable } & \multirow{2}{*}{ Leverage } & Total Debt & \multirow[b]{2}{*}{-} & \multirow{2}{*}{$\begin{array}{c}\text { Financial } \\
\text { Statements }\end{array}$} \\
\hline & & $\overline{\text { Total Equity }}$ & & \\
\hline \multirow{2}{*}{ Independent variable } & \multirow{2}{*}{ Firm Growth } & Net Sales $_{t}-$ Net Sales $_{t-1}$ & \multirow[b]{2}{*}{+} & \multirow{2}{*}{$\begin{array}{c}\text { Financial } \\
\text { Statements }\end{array}$} \\
\hline & & Net Sales $_{t-1}$ & & \\
\hline Independent variable & Firm Age & Current year - establishing year & + & $\begin{array}{c}\text { Financial } \\
\text { Statements }\end{array}$ \\
\hline Independent variable & GDP growth & & + & $\begin{array}{c}\text { Data of } \\
\text { World Bank }\end{array}$ \\
\hline
\end{tabular}

\section{DATA HANDLING}

\subsection{Data description}

The data is collected from audited financial statements of 54 real estate companies listed in Vietnamese stock market. The period under the study ranges from 2010 to 2017, when Vietnamese economy experienced the recession after the financial crisis 2007-2008 and the recovery since then.

Descriptive statistics table is shown in Table 3.

Table 3. Descriptive statistics

\begin{tabular}{ccccccc}
\hline Variable & Obs & Mean & Std. Dev. & $25^{\text {th }}$ percentile & $50^{\text {th }}$ percentile & 75th percentile \\
\hline ROA & 432 & 0.026 & 0.071 & 0.004 & 0.022 & 0.053 \\
SIZE & 432 & 14.213 & 1.255 & 13.222 & 14.077 & 15.159 \\
AGE & 432 & 14.222 & 6.848 & 9 & 13 & 18 \\
GROWTH & 432 & 0.660 & 2.742 & -0.291 & 0.064 & 0.628 \\
LEV & 432 & 1.600 & 1.547 & 0.659 & 1.196 & 2.012 \\
GDP & 8 & 0.061 & 0.005 & 0.057 & 0.062 & 0.065 \\
\hline & & & & & \multicolumn{2}{c}{ Source: calculated by the authors }
\end{tabular}

Average ROA of Vietnamese real estate companies in the period 2010-2017 is 2.6 percent, while the standard deviation is 7.1 percent, reflecting the risky nature of real estate industry. Low standard deviation of SIZE implies that the companies in the sample are relatively comparable. The statistics for GROWTH is affected by extreme value because of the variance in business cycle of each firm. However, the positive and negative outliers have offsetted each other, the mean of GROWTH in overall may not be too distorted. Negative growth existed mainly in the period between 2011 and 2013 when the real estate market decreased as the result of post-crisis recession. Mean of LEV is 1.6, representing the average debt to equity ratio of Vietnamese real estate industry. The value of minimum and maximum value as well as number of observation is showed in Table 3.

\subsection{Unit root tests for panel}

Time-series component in panel makes the data exposed to the likelihood of non-stationarity which may lead to spurious regression. Because the data is micro panel, i.e. relatively short time periods (8 years), common stationary tests for panel data, such as the method of [11] and [8], would not be appropriate as these tests required relatively long time series. The approach of [6] therefore is employed for unit root test of the sample. 
The null hypothesis [6] is that panels contain unit roots, while the alternative hypothesis support the fact that panels are stationary. Result of unit root test according to [6] is illustrated in Table 4.

Table 4. Summary of Unit root test

\begin{tabular}{ccccc}
\hline Variable & Statistic & $\mathrm{Z}$ & p-value & \multicolumn{2}{c}{ Stationarity } \\
\hline ROA & -0.0095 & -14.9071 & 0.0000 & Yes \\
SIZE & 0.8741 & 4.5737 & 1.0000 & No \\
AGE & 1.0000 & 7.3485 & 1.0000 & No \\
GROWTH & -0.2282 & -19.7276 & 0.0000 & Yes \\
LEV & 0.1384 & -11.6463 & 0.0000 & Yes \\
GDP & 0.3977 & -5.9299 & 0.0000 & Yes \\
\hline
\end{tabular}

Unit root tests on original series conclude that SIZE and AGE are non-stationary, suggesting that the regression using these two variables may be not reliable. One of common approaches to handle this problem is replacing the original series by their differentials. However, the differentials of AGE are 1 in every year because of its calculation. Therefore, the meaning of estimated co-efficient for AGE should not be considered. As for variable SIZE, its first differential series is stationary although the use of the first differential reduces the number of observations by the number of firms in the sample.

\subsection{Correlation matrix among variables}

In order to strengthen the prediction of relationship among variables, an analysis of correlation matrix was conducted in Table 5.

Table 5. Correlation matrix

\begin{tabular}{cccccc}
\hline & ROA & GDP & DSIZE & LEV & GROWTH \\
\hline ROA & 1.000 & & & & \\
GDP & 0.056 & 1.000 & & & \\
DSIZE & 0.416 & 0.129 & 1.000 & & \\
LEV & $(0.170)$ & 0.010 & 0.001 & 1.000 & 1.000 \\
GROWTH & $(0.224)$ & 0.069 & $(0.172)$ & 0.004 & Source: calculated by the authors
\end{tabular}

Correlation matrix in Table 5 shows relatively weak correlation among explanatory variables and strong correlation between the groups of explanatory variables and the dependent variable. Firm size measured by the first differential of SIZE has strong positive relationship with firm performance. On the other hand, the correlation between leverage and firm performance may be on the opposite side. GDP growth may have positve impact on firm performance, as being tested in the previous studies, despite the weak correlation shown in the sample. The most unexpected outcome of the correlation analysis is the strong negative relationship between sale growth and performance although the previous studies mostly gave the opposite empirical evidences. Further analysis employing panel regression with threshold in the following section will reveal partly this unexpectation.

\section{RESULT AND DISCUSSION}

\subsection{Results of panel regression model}

Panel regression model is estimated in 3 approaches: Pooled OLS, Fixed Effect Model (FEM) and Random Effect Model (REM). The summary of estimation result is displayed in Table 6.

Between FEM and REM, the Hausman test proposed by [7] for model specification is conducted. The p-value of Hausman test is 0.1922 , greater than the default significant level at 5\%. Therefore the null 
hypothesis of Hausman test cannot be rejected. In this situation, both FEM and REM estimations are robust, but REM is more efficient because it is estimated by General Least Square method.

Table 6. Summary of Model 1

\begin{tabular}{|c|c|c|c|}
\hline & Pooled OLS & FEM & REM \\
\hline \multirow{2}{*}{ GDP } & 0.2433952 & 0.2777343 & 0.2639976 \\
\hline & $(0.682)$ & $(0.594)$ & $(0.613)$ \\
\hline \multirow[t]{2}{*}{ D1.SIZE } & $0.1213384 * * *$ & $0.1105276^{* * *}$ & $0.1144005^{* * *}$ \\
\hline & $(0.000)$ & $(0.000)$ & $(0.000)$ \\
\hline \multirow[t]{2}{*}{ GROWTH } & $-0.0001058^{* * *}$ & $-0.0000805^{* * *}$ & $-0.0000897 * * *$ \\
\hline & $(0.001)$ & $(0.006)$ & $(0.002)$ \\
\hline \multirow[t]{2}{*}{ LEV } & $-0.0073518^{* * *}$ & $-0.0110178^{* * *}$ & $-0.0091382 * * *$ \\
\hline & $(0.0000)$ & $(0.0000)$ & $(0.0000)$ \\
\hline $\mathrm{R}$-square & 0.2263 & 0.2161 & 0.2235 \\
\hline \multirow[t]{2}{*}{ F-statistic } & 27.27 & 23.94 & \\
\hline & $(0.0000)$ & $(0.0000)$ & \\
\hline
\end{tabular}

$(*),(* *),(* * *)$ indicates that the estimated co-efficients are statistical significant at $10 \%, 5 \%, 1 \%$, respectively. Numbers in brackets are p-values. REM does not follow F-distribution, but Chi-square distribution instead.

\subsection{Result of panel regression model with threshold}

Source: calculated by the authors

The empirical result in Section 5.1 can be enhanced by threshold regression. The threshold variable used in this research is LEV, the debt to equity ratio. We follow the idea of optimal capital structure proposed by [16]. The leverage threshold effect on ROA was discovered and confirmed in papers of [2] and [13]. However, leverage threshold of firm performance in Vietnamese real estate industry has not studied so far.

Threshold effect is tested by the approach of [5] who proposed bootstrap procedure to estimate the co-efficients of region-varying variables. GDP is the only variable which we consider region-invarying. In the other words, impact of GDP on firm performance is less dependent on leverage threshold effect.

Table 7. Result of threshold effect test and threshold estimator

\begin{tabular}{|c|c|c|c|c|c|c|c|}
\hline Model & Threshold & Lower & Upper & & & & \\
\hline Single threshold & 0.383 & 0.3733 & 0.386 & & & & \\
\hline Threshold & RSS & MSE & Fstat & Prob & Crit10 & Crit5 & Crit1 \\
\hline Single & 0.799 & 0.0022 & 64.64 & 0.022 & 31.2081 & 42.9117 & 79.7314 \\
\hline
\end{tabular}

Table 7 illustrates the result of threshold estimation using 1000 times of bootstrap. The single threshold for leverage is 0.383 which divide the impact of region-varying variables into two categories.

The Table 8 shows the summary of Model 2, the panel regression with threshold. The estimated results take into account of the correction for heteroskedasticity. The standard errors, therefore, were recalculated to be robusted. As for the problems with multicolinearity and serial correlation, the related diagnosing tests did not find the statistical evidences for their existence at 5\% of significant level.

At the leverage threshold at 0.383 , the impact of LEV, GROWTH and the first differential of SIZE vary significantly. Surprisingly, below the threshold, the significance of influences made by leverage, growth and percentage change of firm size is rejected. The impacts of those determinants are only significant when leverage passes the threshold. The leverage threshold thus may be considered as an optimal level of debt to equity ratio. Negative impact of leverage is confirmed in this study, but only in high levered firms. Similarly, the change of firm size influences positively on ROA of companies with 
debt to equity ratio higher than 0.383 . However, the firm growth shows a negative correlation with ROA in the group of highly levered companies.

Table 8. Summary of Model 2

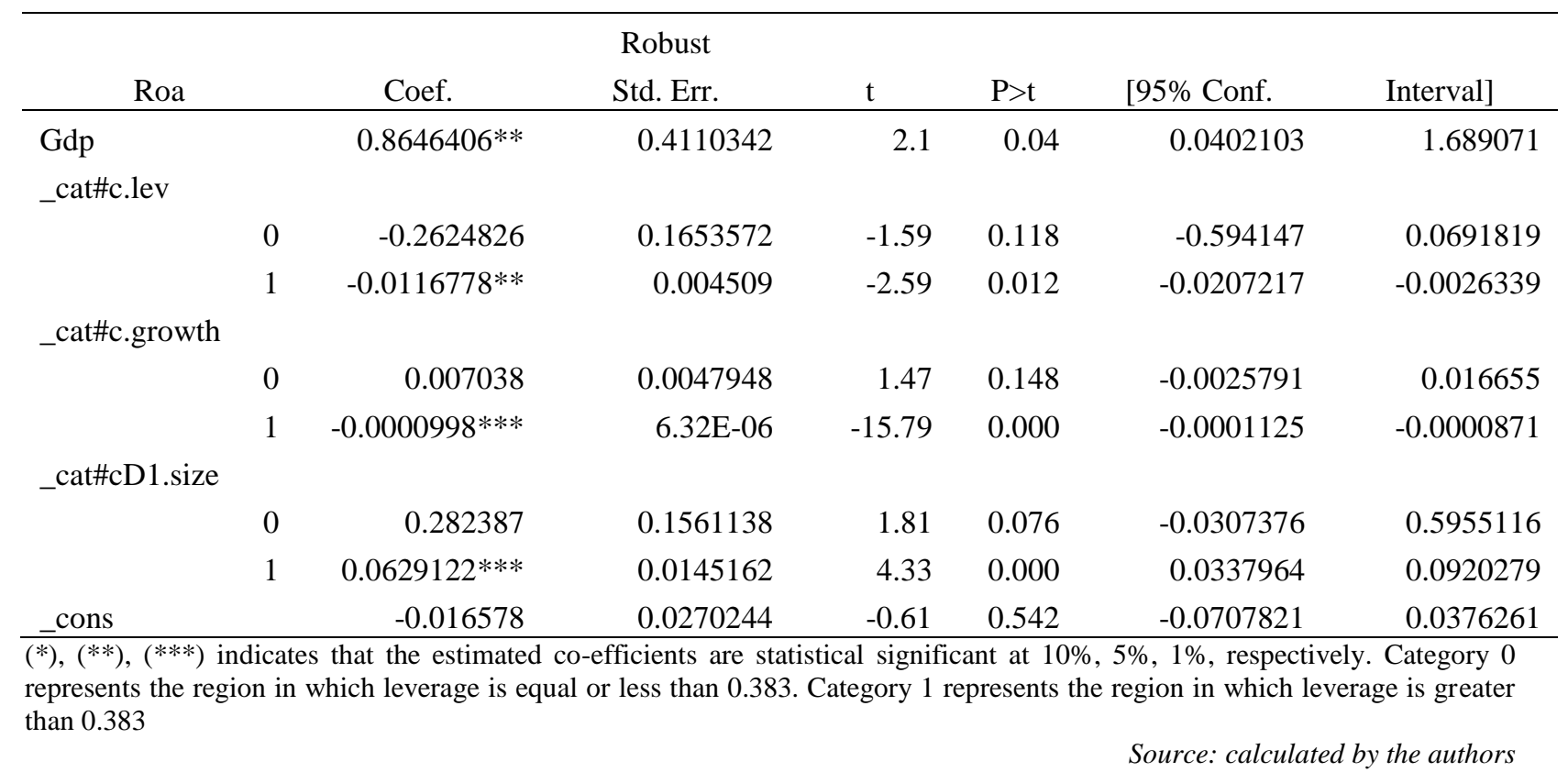

\subsection{Discussion}

Debt financing is a crucial source of capital, especially in the case of Vietnamese real estate industry. The expansionary monetary policy and preferential credit packages for real estate investment in recent years have encouraged the use of additional debt in real estate companies as well as the rapid growth of real estate market. Overleverage becomes common in this industry and changes the impacts of the determinants on firm performance.

The fact that there would be no significant impact of firm growth, size and leverage on performance of less levered companies may improve conclusions derived from the previous studies on this topic. The leverage threshold is far lower than the average debt ratio of the sample, i.e. 1.6, inferring that the observations in Category 0 are the minority in the sample. It is possible that performance of real estate companies with no or little debt compared to the norms seems to be unpredictable with the use of growth, leverage or firm size. On the other hand, firm performance of greater-than- 0.383 debt ratio would show a more "visual" behaviour.

The negative sign of LEV's co-efficient is the statistical evidence for our hypothesis. When debt ratio exceeds 0.383 , the additional debt may reduce firm performance. The finding agrees with statements of most previous studies, except [12]. However, the inversed conclusion which argues for positive impact of leverage in less levered companies cannot be confirmed. The management team should not use leverage to increase firm performance for that reason.

Although most previous studies found the positive co-movement of revenue growth rate and firm performance, this study did not empirical evidence for that relationship. In case of low level of debt, the significance of growth is rejected. At high level of debt, real estate companies are faced to more pressure of generating cash flows to repay the debt. The management therefore pays more attention to sales target at the expense of profit because real estate is a special product whose liquidity may not be consistent. In this situation, the growth is low quality and harmful to firm performance.

Impact of the first differential of firm size on firm performance is positive if leverage is higher than the threshold and is still significant at $10 \%$ if the leverage lies below the threshold. The size effect can be explained by either economies of scale, competitive advantage, or access to finance. In Vietnam context, the firm size is vital in competition because big firms possess valuable lands in large scale. These players 
thus hold huge advantages in competition and connection with major banks. In recent years, the trend of M\&A in Vietnamese real estate companies can be justified by this argument.

The threshold model also rejects the insignificance of GDP growth which the Model 1 could not do the same. The impact of GDP growth is once again confirmed, strengthening the empirical evidence of [1].

\section{CONCLUSION}

This paper has extended empirical results of previous studies on the determinants of firm performance in Vietnamese listed real estate companies. We found the evidence of leverage threshold which affects the influence of firm growth, firm size and leverage itself on firm performance measured by the return on asset. Therefore, the impacts of those determinants are partly significant. Below the leverage threshold, most determinants except firm size are proved to have no significant influence on firm performance. The expected relationships are able to be found in the region above the threshold.

The fragmented impacts suggest researchers and managers to be more prudential when considering policies that enhance the firm performance. In a changing world, the non-linear approach would be more applicable to analyse economic relationships.

As for further researches, more advanced threshold variables should be studied and tested for their statistical significance. The time variable can be employed to evidence the structural break of timevarying economic links, while lagged variables will be more meaningful for forecasting purposes.

\section{REFERENCE}

[1] Bui, N. T. (2016). Impacts of Working Capital Policy on Return on Asset of Vietnamese Real Estate Companies. Journal of Can Tho University, 2016, 18-27.

[2] Cheng, Y. S., Liu, Y. P., \& Chien, C. Y. (2010). Capital structure and firm value in China: A panel threshold regression analysis. African Journal of Business Management, 4(12), 2500-2507.

[3] Do, D. T. N. (2011). Financial Factors of Firm Performance in Construction Companies Listed in Vietnamese Stock Market. (Master dissertation, University of Economics of Hochiminh City, Vietnam)

[4] Frank, M. Z. (1988). An intertemporal model of industrial exit. The Quarterly Journal of Economics, 103(2), 333-344.

[5] Hansen, B. E. (1999). Threshold effects in non-dynamic panels: Estimation, testing, and inference. Journal of econometrics, 93(2), 345-368.

[6] Harris, R. D., \& Tzavalis, E. (1999). Inference for unit roots in dynamic panels where the time dimension is fixed. Journal of econometrics, 91(2), 201-226.

[7] Hausman, J. A. (1978). Specification tests in econometrics. Econometrica: Journal of the econometric society, 1251-1271.

[8] Im, K. S., Pesaran, M. H., \& Shin, Y. (2003). Testing for unit roots in heterogeneous panels. Journal of econometrics, 115(1), 53-74.

[9] Jovanovic, B. (1982). Selection and the Evolution of Industry. Econometrica: Journal of the Econometric Society, 649-670.

[10] Kouser, R., Bano, T., Azeem, M., \& Ul Hassan, M. (2012). Inter-relationship between profitability, growth and size: A case of non-financial companies from Pakistan. Pakistan Journal of Commerce and Social Sciences (PJCSS), 6(2), 405-419. 
[11] Levin, A., Lin, C. F., \& Chu, C. S. J. (2002). Unit root tests in panel data: asymptotic and finite-sample properties. Journal of econometrics, 108(1), 1-24.

[12] Liargovas, P. G., \& Skandalis, K. S. (2010). Factors affecting firms' performance: The case of Greece. Global Business and Management Research: An International Journal, 2(2), 184-197.

[13] Lin, F. L., \& Chang, T. (2011). Does debt affect firm value in Taiwan? A panel threshold regression analysis. Applied Economics, 43(1), 117-128.

[14] Ly, X.H (2017). Determinants of firm performance of Vietnamese listed real estate companies.( Master dissertation, University of Finance and Marketing, Vietnam)

[15] Modigliani, F., \& Miller, M. H. (1963). Corporate income taxes and the cost of capital: a correction. The American economic review, 53(3), 433-443.

[16] Murphy, G. B., Trailer, J. W., \& Hill, R. C. (1996). Measuring performance in entrepreneurship research. Journal of business research, 36(1), 15-23.

[17] Mwangi, M., \& Murigu, J. W. (2015). The determinants of financial performance in general insurance companies in Kenya. European Scientific Journal, ESJ, 11(1).

[18] Onaolapo, A. A., \& Kajola, S. O. (2010). Capital Structure and Firm Performance: evidence from Nigeria. European Journal of Economics, Finance and Administrative Sciences, 25, 70-82.

[19] Quan, M. N, \& Ly, T. P. T (2014). Analyzing Factors Affecting Firm Performance of Real Estate Companies Listed on Vietnamese Stock Market. Journal of Can Tho University, 33, 65-71.

[20] Safarova, Y. (2010). Factors that determine firm performance of New Zealand listed companies (Doctoral dissertation, Auckland University of Technology).

[21] Savills (2018). Vietnam Residential: Where to from here? Available at: http://pdf.savills.asia/asia-pacificresearch/vietnam-research/spotlight/vietnam-residential-20181127-en.pdf

[22] World Bank (2019). Open data by indicator. Available at: https://data.worldbank.org/indicator/NY.GDP.MKTP.KD.ZG?locations=VN

[23] Yeh, M. L., Chu, H. P., Sher, P. J., \& Chiu, Y. C. (2010). R\&D intensity, firm performance and the identification of the threshold: fresh evidence from the panel threshold regression model. Applied economics, 42(3), 389-401.

[24] Zeitun, R., \& Tian, G. G. (2007). Capital Structure and Firm Performance: Evidence from Jordan. Australia Accounting Business and Finance Journal, 1(4), 148-168..

Received on February 1st, 2019

Accepted on March 25th, 2019 